\title{
Wyznaczniki kształtowania się tożsamości psychospołecznej osób z niepełnosprawnością intelektualną w stopniu umiarkowanym
}

Klaudia Izabela Majewska

https://orcid.org/0000-0003-1549-6400 Akademia Pedagogiki Specjalnej im. Marii Grzegorzewskiej 


\section{Streszczenie}

Przedmiotem badań własnych jest wyznaczenie czynników kształtowania się tożsamości psychospołecznej osób z niepełnosprawnością intelektualną w stopniu umiarkowanym. Tożsamość psychospołeczna jest ważną składową osobowości człowieka. Osoby z niepełnosprawnością intelektualną, z racji zaburzeń w sferze poznawczej i emocjonalno-społecznej, mogą tworzyć zniekształcony obraz swojej tożsamości. W związku z tym warto zbadać tematykę kształtowania się tożsamości psychospołecznej osób z niepełnosprawnością intelektualną w stopniu umiarkowanym i spróbować wyznaczyć czynniki warunkujące jej ukształtowanie.

Problemy ten starano się rozwiązać poprzez analizę danych, zebranych za pomocą metody sondażu diagnostycznego oraz techniki wywiadu. Narzędzie badawcze, które zostało użyte do zebrania danych, to kwestionariusz wywiadu. Badaniem objęto siedem dorosłych osób z niepełnosprawnością intelektualną w stopniu umiarkowanym.

\section{Słowa kluczowe}

niepełnosprawność intelektualna, tożsamość osobowa, tożsamość psychospołeczna, sondaż diagnostyczny.

\section{DEFINICJE TOŻSAMOŚCI OSOBOWEJ I SPOŁECZNEJ}

$\mathrm{P}$ ojęcie tożsamość ego zostało wprowadzone do psychologii przez Erika H. Eriksona. Mówi ono o tym, że tożsamość osobowa jest to proces, który trwa od dzieciństwa aż do okresu dorastania, w którym to następuje ustalenie i utrwalenie cech określających tożsamość. Usystematyzowany zestaw cech osiągniętych w procesie tworzenia się tożsamości decyduje następnie o jakości życia w okresie dorosłości (Brzezińska, Piotrowski 2010).

Tożsamością osobową nazwać można „istnienie w pamięci jednostki względnie stałego zestawu elementów, które człowiek uznaje za definiujące jego osobę i pozwalające na uzyskiwanie odpowiedzi na podstawowe pytania tożsamościowe: Kim jestem? Kim chcę być? Do czego dążę?" (Piotrowski 2013: 47). Autor zwraca uwagę na subiektywne cechy, które w ciągu swojego życia odkrywa jednostka. Piotrowski podkreśla również, że atrybuty, jakimi osoba określa samą siebie, są skutkiem autorefleksji, ponieważ człowiek w tym procesie musi dokonać krytycznej oceny swoich przekonań. Tożsamość osobowa związana jest z umiejętnością zaprezentowania jakiejś definicji samego siebie. Żeby tego dokonać, potrzebna jest wiedza poznawcza na temat własnej osoby. Definicja ta powinna być na tyle dokładna, by mogła odróżnić osobę definiowaną od innych (Piotrowski 2013: 47).

Tożsamość społeczna polega na świadomości przynależenia do różnych grup społecznych, pozwala na określenie siebie względem innych grup. Stworzona w 1986 r. przez Tajfela i Turnera teoria tożsamości społecznej „zakłada, że istnieje tendencja do kategoryzowania spotkanych ludzi, przy czym ważnym elementem jest podział na grupę, z którą identyfikuje się podmiot („my”) oraz pozostałe” (Wojciszke 2002: 74). Autor zwraca uwagę na to, że ludzie mają tendencję do oceniania innych względem grup, z którymi się utożsamiają. W procesie tym ocena jest powierzchowna i zdominowania 
przez przypuszczenia i stereotypy. Przynależność do grup społecznych o wysokim statusie jest uważane za ważne źródło pozytywnej samooceny. Wojciszke twierdzi, że „faworyzowanie własnej grupy nasila tożsamość społeczną, zatem, na co teoria tożsamości społecznej wskazuje, sukcesy w rywalizacji z innymi grupami wzmacniają identyfikację jej członków z grupą zwycięską. Mechanizm działa również w drugą stronę - spadek samooceny będzie nasilać faworyzację grupy własnej przy jednoczesnym deprecjonowaniu wartości grup innych". Ważnym elementem w rozwoju tożsamości społecznej jest więc przynależność do grup społecznych, które są zauważane i doceniane przez inne grupy. Sukcesy grupy, do której czuje się przynależna, jednostka odbiera jako sukces własny, zwiększając swoją samoocenę, nawet gdy osoba ta nie miała żadnego wkładu w osiągnięty wynik.

Warto również zaznaczyć, że tożsamość społeczna i tożsamość osobowa wywierają, w mniejszym lub większym stopniu, wpływ na siebie nawzajem. Zdaniem Anthony’ego Giddensa (2008) utrzymanie stałej i niezmiennej tożsamości w trakcie życia w obliczu wpływów nowoczesnego społeczeństwa jest dla zdecydowanej większości osób bardzo trudne. Mimo że według autora społeczeństwo nie posiada władzy absolutnej w procesie kształcenia tożsamości jednostki, to znacząco wpływa na cechy, które w okresie kształtowania się tożsamości jednostka przyjmuje jako własne. Między tożsamością osobową i społeczną istnieje zależność odwrotna. Jeśli jednostka będzie poświęcać za dużo uwagi rozwojowi tożsamości osobowej, utraci w tym wszystkim zainteresowanie tożsamością społeczną, analogicznie, gdy zbyt dużo zasobów przeznaczać będzie na poczet przynależności do grupy, zatraci poczucie własnego „ja” i jej tożsamość osobowa ulegnie rozproszeniu (Ambrozik, Kieszkowska 2012).

\section{TOŻSAMOŚĆ SPOŁECZNA I OSOBOWA OSÓB Z NIEPEŁNOSPRAWNOŚCIĄ INTELEKTUALNĄ}

Temat tożsamości osób z niepełnosprawnością intelektualną jest mało popularny wśród badaczy, dlatego też zasób danych dotyczących tego zjawiska jest dość ubogi. Zagadnienie tożsamości osób z niepełnosprawnością intelektualną jest pomijane, ponieważ osoby te można zaliczyć do tak zwanej „zapomnianej połowy” (forgotten half). Określenia tego użył Seth Schwartz (2005) w stosunku do osób, wśród których badania na temat tożsamości nie były nigdy przeprowadzane lub były przeprowadzane w sposób pobieżny. Do grupy tej autor zalicza m.in. osoby nieuczące się, ubogie czy należące do mniejszości.

Na badania poświęcone tożsamości osób $\mathrm{z}$ niepełnosprawnościami - w tym niepełnosprawnością intelektualną - zwrócił uwagę Piotrowski. Pisze on o tym, że w przypadku osób z ograniczonymi umiejętnościami poznawczymi wykazano niższą, w porównaniu do osób z innymi niepełnosprawnościami, aktywność społeczną. W związku z ograniczeniami poznawczymi, osoby z niepełnosprawnością intelektualną radzą sobie również gorzej z realizacją zadań rozwojowych oraz mają trudności w rozwoju zawodowym. Wpływ na to ma, zdaniem autora, duża zależność osób z niepełnosprawnością intelektualną od 
innych oraz nadopiekuńczość rodziców, rodziny czy prawnych opiekunów. Zwrócono uwagę również na to, że ograniczenia $\mathrm{w}$ sferze poznawczej „znajdują $\mathrm{z}$ kolei proste przełożenie na gorsze funkcjonowanie $\mathrm{w}$ relacjach interpersonalnych, a realizowanie zadań rozwojowych odbywa się właśnie w przestrzeni społecznej" (Piotrowski 2013: 87). $\mathrm{W}$ związku z tym, że osobom z niepełnosprawnością intelektualną kontakty $\mathrm{z}$ innymi ludźmi, z różnych powodów, często sprawiają trudność, przekłada się to na przebieg procesu tworzenia tożsamości. Niepełnosprawność intelektualna oraz trudności, jakie się z nią często wiążą, skutkują koniecznością dbania o swój stan zdrowia (przyjmowanie leków, rehabilitacja, terapie, itp.) bardziej niż rozwojem swojego „ja”. Świadomość barier (fizycznych, jak i psychicznych) ograniczających (w rzeczywistości czy tylko w wyobraźni) możliwości uczestnictwa w niektórych obszarach życia społecznego jest związana z obniżoną aktywnością obserwacji i doświadczania potencjalnych tożsamości. Prowadzi to bardzo często do rozproszenia swojej własnej tożsamości i przyjęcia łatwo dostępnych, nierzadko narzuconych lub zasugerowanych alternatyw, które niekoniecznie nakładają się na osobiste preferencje (tamże).

\section{SPECYFIKA KSZTAŁTOWANIA SIĘ TOŻSAMOŚCI OSÓB Z NIEPEŁNOSPRAWNOŚCIĄ INTELEKTUALNĄ}

Funkcjonowanie człowieka podzielić można na trzy sfery: psyche, soma i polis. Sfery te opisują człowieka jako istotę społeczną, która jest zależna od społeczeństwa (polis), istotę biologiczną, która posiada swoje ograniczenia, możliwości oraz jest wrażliwa na uszkodzenia (soma), istotę autonomiczną, która potrafi obserwować, wyciągać wnioski, analizować oraz podejmować decyzje (psyche). Ta perspektywa ujawnia zależności między ciałem, psychiką i życiem w społeczeństwie. Osoby z niepełnosprawnością intelektualną często mają trudności w sferze psychologiczno-społecznej, co może znacząco wpływać na proces tworzenia się tożsamości (Brzezińska 2000).

Stanisław Kowalik (1999) zauważa, że osoby z niepełnosprawnością mają trudności w ułożeniu swojego życia w szerszej perspektywie czasowej. Powoduje to wątpliwości związane z przyszłą jakością życia oraz strach o własną przyszłość. Najczęściej strach ten związany jest z uzyskaniem zawodu, wykształceniem, założeniem własnej rodziny oraz życiem społecznym.

Zauważyć można, że niepełnosprawność intelektualna jest czynnikiem, który wpływa (lecz nie warunkuje) na samopoczucie, sytuację społeczną oraz psychofizyczny stan człowieka. W procesie tworzenia tożsamości jednostka porównuje się z innymi ludźmi, częściej dostrzegając różnice niż podobieństwa. Poczucie tożsamości określa się przede wszystkim jako świadomość własnego istnienia, jego wartości, trwałości, ale również autonomii oraz niezależności. Osoby z niepełnosprawnością intelektualną z łatwością potrafią dostrzec swoją odmienność od społeczeństwa, jednak nie zapewnia to utworzenia się tożsamości na fundamentach poczucia własnej wartości oraz kompetencji (Stelter 2007: 184). 


\section{METODOLOGIA BADAŃ WŁASNYCH}

Celem mojego badania było wyznaczenie czynników kształtowania się tożsamości psychospołecznej osób z niepełnosprawnością intelektualną w stopniu umiarkowanym. Sformułowałam problem główny oraz następujące problemy szczegółowe:

Problem główny:

- Jakie są wyznaczniki kształtowania się tożsamości osób z niepełnosprawnością intelektualną w stopniu umiarkowanym?

Problemy szczegółowe:

- Jak osoba $\mathrm{z}$ niepełnosprawnością intelektualną w stopniu umiarkowanym postrzega siebie?

- Jak osoba z niepełnosprawnością intelektualną w stopniu umiarkowanym myśli, że jest postrzegana?

- Jaką rolę w procesie tworzenia tożsamości osób z niepełnosprawnością intelektualną w stopniu umiarkowanym pełnią osoby najbliższe?

- Jak plany i marzenia definiują tożsamość osoby z niepełnosprawnością intelektualna w stopniu umiarkowanym?

\section{CHARAKTERYSTYKA WYBRANYCH METOD, TECHNIK I NARZĘDZI BADAWCZYCH}

Metodą, której użyłam na potrzeby swojej pracy badawczej, jest sondaż diagnostyczny. Za jej pomocą można uzyskać odpowiednią wiedzę na temat określonych zjawisk w danej grupie społecznej. T. Pilch (2001: 80) opisuje tę metodę jako „sposób gromadzenia wiedzy o atrybutach strukturalnych i funkcjonalnych oraz dynamice zjawisk społecznych, opiniach i poglądach wybranych zbiorowości, nasilaniu się kierunków rozwoju określonych zjawisk instytucjonalnych niezlokalizowanych, posiadających znaczenie wychowawcze, w oparciu o specjalnie dobraną grupę reprezentującą populację generalną, w której badane zjawisko występuje".

W swoich badaniach użyłam techniki badawczej, jaką jest wywiad. Charakteryzuje się on swobodną rozmową badanego z osobą lub osobami badanymi. Do przeprowadzenia wywiadu można również użyć wcześniej opracowanego kwestionariusza. Zdaniem T. Pilcha (2001: 92) „wywiad służy głównie do poznawania faktów, opinii i postaw danej zbiorowości".

Narzędziem badawczym, które posłużyło mi do zebrania danych, był kwestionariusz wywiadu. 


\section{CHARAKTERYSTYKA GRUPY BADAWCZEJ}

Grupa badawcza, na której przeprowadziłam badanie, stanowiły dorosłe osoby z niepełnosprawnością intelektualną w stopniu umiarkowanym. Wszyscy badani mieszkają na terenie Warszawy. W badaniu udział wzięło 7 osób, w tym 6 mężczyzn oraz jedna kobieta.

W grupie badawczej znajdowała się 1 osoba w przedziale wiekowym 25-35 lat, 4 osoby w przedziale wiekowym 36-45 lat oraz 2 osoby powyżej 46 . r.ż.

\section{PREZENTACJA WYNIKÓW BADAŃ WŁASNYCH}

\section{Jak osoba z niepełnosprawnością intelektualną w stopniu umiarkowanym postrzega siebie?}

Pierwszą sferą, która może wskazać na wyznaczniki kształtujące tożsamość psychospołeczną, jest obraz własnego „Ja”.

Na pytanie „Opowiedz mi o sobie?” można wyróżnić kilka typów odpowiedzi. Niektórzy badani w swojej wypowiedzi zwracali uwagę na ośrodek, do którego uczęszczają na co dzień.

Nazywam się B. W. uczęszczam do ośrodka [...] prowadzonego przez Warszawskie Koło Polskiego Stowarzyszenia na rzecz Osób z Niepełnosprawnością Intelektualną. (B.W.)

Co robię... chodzę do ośrodka na ulicy [...]. Chodzę do ośrodka. (M.I.)

Inni badani zaczynali od przedstawienia swoich zainteresowań, rzeczy, które lubią robić, które sprawiają im przyjemność.

Mam dużo zainteresowań. Na przykład ten... szyję sobie czasami, tak jak Ci opowiadałam. No mam... ten... czasami podszywam, jak coś się odpruje to takim haftem specjalnym. I ten... I wszystko, co jest właśnie w tych... możliwościach... I jestem z tego zadowolona, że chciałabym właśnie coś z tego mieć. (K.J.)

O sobie? Pomagam wszystkim... wynosić śmieci... sprzątać... zawsze robię... I jeszcze... kolegom i koleżankom pomagam. Lubię wynosić śmieci. (P.G.)

Dwie osoby w swojej wypowiedzi wymieniły szkoły, do których uczęszczały, nie uwzględniając ośrodka, do którego uczęszczają obecnie.

Chodziłem kiedyś do szkoły na Górnym Mokotowie. Jestem historykiem, lubię historię od starożytnego Egiptu do nowoczesności... Tak, historia starożytna, historia nowoczesna, i od pierwszej wojny światowej do drugiej, o Tatarach, o Mongołach. (A.N.) 
Tylko jedna wypowiedź jednoznacznie charakteryzowała się stwierdzeniem „jestem osobą z niepełnosprawnością intelektualną".

Yyy... o sobie mogę powiedzieć tylko tyle, że jestem osobą z niepełnosprawnością intelektualną. Pracuję... yyy... uczęszczam na zajęcia do ŚDŚ. Ogółem fajnie jest..., czasem jest ciężko, sytuacja życiowa czy coś, ale zawsze daję sobie radę. (M.G.)

Przy pytaniu „opowiedz mi o swojej niepełnosprawności?” tylko dwie osoby badane potrafiły jasno powiedzieć oraz nazwać niepełnosprawność, jaką posiadają.

Wiem, że jestem niepełnosprawny od urodzenia. Trudno to powiedzieć, ale... Moja niepełnosprawność polega na tym, że nie umiem kartofli obrać ani bułek ukroić... Zespół Downa! O! Właśnie z tym się urodziłem. Tutaj jak jestem to... jeszcze mieszkałem w takim mieszkaniu chronionym, treningowym na [...] i tam się nauczyłem dużo rzeczy takich jak sprzątanie, porządki, zakupy, samodzielność, sprzątanie po sobie..., takich rzeczy. (A.N.)

Ojej! Ooo! No..., urodziłem się z dziecięcym porażeniem mózgowym, które jest od urodzenia... ciężko jest nieraz. Jest ciężko, nieraz jest łatwo. Nieraz nie przyznaję się do tego, że jestem niepełnosprawny. (M.G.)

Dwoje badanych nie potrafiło nazwać swojej niepełnosprawności, lecz opisali ją w postaci ograniczeń, jakie posiadają.

O niepełnosprawności... Tata nauczył kiedyś mnie jeździć rowerem. Umiem jeździć na rowerze..., umiem bardzo. Chciałbym się nauczyć jeszcze jeździć na skuterze..., ale nie mogę. To za trudne dla mnie za bardzo. Kiedyś tata uczył mnie jeszcze jeździć samochodem. Naprawdę! Nie mogłem dalej..., biegi umiem, a dalej nie umiem. (A.S.)

Niepełnosprawności... to ten..., mam skrzywienie kręgosłupa bardzo. I dlatego te ćwiczenia mam, co Ci pokazywałam wcześniej. I te..., no ćwiczenia, trochę mi pomagają tu... W tej części prawej, bo mam najbardziej tutaj część prawą bardzo sparaliżowaną. No i tak to ogólnie się dobrze czuję. Ogólnie to mnie nic na razie nie boli, ale to wszystko będzie wychodziło... Czym będę starsza, tym bardziej to wszystko będzie wychodziło. No i na razie jakoś się odnajduję. Miałam nogę jedną złamaną..., drugą złamaną aż do pachwiny..., po prostu. (K.J.)

Jeden badany stwierdził brak u siebie jakiejkolwiek niepełnosprawności.

O niepełnosprawności? Nie mam. Już nie mam... niepełnosprawności. Na lepsze się zmieniam. (P.G.)

W pytaniu "Jaki masz charakter?" troje badanych zaczęło opisywać siebie, używając pozytywnych określeń, pamiętając również o swoich słabszych stronach. 
Jestem spokojny, tak spokojny jestem. Diabłem nie jestem, kiedyś byłem wulgarny, ale jestem... zmobilizowany do działania, chcę działać we własnym zakresie, to mnie uszczęśliwia. Ale jak się wkurzę, to potrafię być niebezpieczny. Emocjonalny też jestem czasami, wkurzający, czasami jestem wulgarny, ale jak mi odbije. Ale na co dzień spokojny, inteligentny, miły kulturalny. Jak ktoś do mnie podchodzi, to... to umiem nawiązać kontakt osobisty. Z Markiem, z którym tu mieszkam, przyjacielem moim. No... przyjaźnimy się, mieszkamy razem, chodzimy razem do ośrodka, tam jesteśmy też przywiązani jak bracia i taka jest moja cecha. Kulturalność, przyjaźń i staram się, żeby inni mogli mi zaufać wzajemnie. (A.N.)

Dobry, miły sympatyczny, wesoły. Czasami jak ktoś mnie zdenerwuje, to coś tam powiem, ale ogólnie to mówię słowo "przepraszam”, "proszę”, „dziękuję" i wszystko idzie ku dobremu, że jestem taką osobą. I mówią, że bardzo jestem taka uprzejma, że ustępuję czasami miejsca w autobusie czy w tramwaju i wszyscy są ze mnie zadowoleni, że od małego jestem tego uczona. I czasami w metrze... jak jadę w metrze, to też mówią. (K. J.)

Charakter... uuu... No dobry charakter. Taki... no... spokojny charakter. Jak ktoś mnie nie zdenerwuje, to potrafię być niespokojny. No ale jak na przykład trzeba stanąć w obronie słabszej osoby, wiedząc, że ja jestem słabszą osobą, to mimo że jestem słabszą osobą, to potrafię innym pomóc też. (M. G.)

Inna trójka badanych opisała swój charakter bardzo krótko, zwięźle i w samych superlatywach.

Charakter? Taki grzeczny, łagodny, mily i przyjemny. (A.S.)

Charakter? Dobry. Jestem najlepszy, uczciwy, porządny... i jeszcze... charakter to jest... kulturalny. (P.G.)

Mam dobry charakter... tak..., w ośrodku dobry..., w mieszkaniu dobry... Mam dobry charakter... (M. I.)

Jeden badany skupił się jedynie na swoich gorszych cechach charakteru, trudnościach. W swojej wypowiedzi nie uwzględnił ani jednej dobrej cechy.

Jestem... wybuchowy. Czasami jak dochodzi do awantur... czasami jak... też mogę Ci wspomnieć... jestem byłym alkoholikiem. Nadużywałem alkoholu swego czasu. Jeszcze jak mamusia żyła... Wtedy... jak to się mówi... dostawałem małpiego rozumu. Wtedy wpadałem w niekontrolowaną furię alkoholową. Dwa razy byłem w szpitalu na odwyku. I jak tu jestem, to się staram... kontrolować takie wybuchy. Bardziej... słownie coś powiem... czasami jest tak, że... nie przemyślę tylko od razu mówię - prosto, zwięźle i na temat. Strasznie szybko się denerwuję... bardzo szybko. ( B. W.)

Przy pytaniu „Co lubisz robić najbardziej?” można zauważyć dosyć duże zróżnicowanie co do zainteresowań i hobby osób badanych. Najczęściej występującą czynnością jest słuchanie muzyki. Innymi zainteresowaniami są m.in. spacery, podróże, haftowanie, ma- 
lowanie czy majsterkowanie. Warto też zaznaczyć, że obsługa urządzeń elektronicznych (smartfon, komputer) nie jest im obca.

W kuchni najbardziej lubię robić kanapki..., gotować też potrafię. W ośrodku albo tu w mieszkaniu. Spacery lubię, jak jestem u mamy, ale jak jestem tu, to też spacerować lubię. Lubię... yyy... jeździć po Warszawie. W ramach samodzielności to jeszcze powiem $\mathrm{Ci}$, że często podróżuję po Warszawie..., ale autobusem, bo samochodem nie umiem jeździć. (A.N.)

Jak mam telefon, to lubię grać na nim. Jak nie mam telefonu, to skupiam się na rysunkach lub innych pracach..., mogę pokazać. Od zawsze, jak pamiętam, maluję.(B.W.)

Najbardziej lubię wyszywać jak kupię sobie takie fajne... obruski czy... serwetki takie fajne. To lubię wyszywać sobie... albo haftować igłą taką cieniutką. I wyrabiam sobie jeszcze... wyrabiam sobie właśnie tą manualność, to co lubię robić. (K. J.)

Słuchać muzyki. Spotykać się ze znajomymi. Siedzi się tam nieraz na facebooku jak się nudzi, czy coś. (M. G.)

Robić... coś tam... pisanie różne listy... czy filmowe... czy z muzyką. Muzyki słucham. Majsterkuję... jak tata żył, to robiliśmy modele, dłubaliśmy w drewnie, no... Tata lubił stolarkę, sam zrobił remont domu. Trochę pomagałem. (A.S.)

Słuchać muzyki. Słuchanie muzyki to jest moje hobby i słuchania... słucham CamySutry. Wiesz co to jest? To takie Disco Polo. Jak przychodzę do nas do ośrodka to podpinam laptopa, słuchawki, myszkę, zasilacz i sobie słucham CamySutry i... już jestem w jej zespole... i w chórkach śpiewam. Tylko to. (P.G.)

W ośrodku na zajęciach komputerowych. Wolę grać w grę... Pinball... wolę grać u Pana Adama. (M.I.)

Przy pytaniu „Czy często potrzebujesz pomocy od innych?” większość badanych widzi siebie jako osoby bardzo samodzielne. Jednak czasami w ich dalszych wypowiedziach podają przykłady sytuacji, w których jednak tej pomocy potrzebują. Są to proste czynności dnia codziennego, takie jak zrobienie prania, golenie brody, zrobienie herbaty czy wstawianie naczyń do zmywarki.

Na razie nie. Jakoś sobie daje sama radę. Jak coś tam od taty potrzebuję, to tata mi pomaga w różnych tam rzeczach. Ale tak to nie. Samodzielna jestem. Sama się poruszam po mieście..., wszędzie się poruszam. (K.J.)

No to to przy goleniu. a tak to sam robię. Wykąpię się sam. Mama umyje tylko głowę, plecki a tak to sam. Od góry do dołu. Pranie... czasem sam sobie upiorę rzeczy, ale mama musi całkiem uprać... rzeczy. Ja pranie raz..., mama drugi raz musi prać i jest ok. (A.S.) 
Pomocy... jak nie mogę osłodzić herbaty, to kogoś proszę o pomoc. Czy od tego czy od innego. (P.G.)

Często ja nie potrzebuję... Czasem potrzebuję... Jak trzeba coś..., żeby coś wycierać..., jak wyjmuję ze zmywarki..., jak trzeba wstawić do zmywarki. (M.I.)

Z wypowiedzi dwojga badanych można stwierdzić, że bardziej niż pomocy w czynnościach manualnych, potrzebują pomocy przy radzeniu sobie z emocjami.

Tak. Jak mi coś nie wyjdzie, to wtedy proszę o pomoc. Jak coś zbiję, to proszę o pomoc. A u Marka jest tak, że jak coś zbije, to lecę mu pomóc z tym sprzątaniem właśnie. Pomagam, jak śmiecie trzeba wynieść. (A.N.)

Jak są takie sytuacje patowe, to... bardziej wolę... pomocy. Czasami jak się denerwuję... coś źle powiem to... wolę pójść do Pana Konrada, jest moim terapeutą... pójdę, porozmawiam. Sprzątanie czy jakieś takie rzeczy to sobie radzę. (B.W.)

Podsumowując, z wypowiedzi osób badanych można stwierdzić, że osoby badane starały się najczęściej udzielać odpowiedzi w jak najbardziej korzystny dla siebie sposób. Tylko niektórzy badani byli w pełni świadomi swojej niepełnosprawności i otwarcie o niej mówili. Przyczyn nierozmawiania na temat niepełnosprawności można szukać w poczuciu wstydu bądź próbie wyparcia tej informacji. Akceptacja stanu, w jakim się znajduje, zdaje się być kluczowa w procesie kształtowania się prawidłowego, niczym nie zniekształconego obrazu własnego „Ja”. Próby opisania swojego charakteru najczęściej skutkowały wymienieniem wyuczonych wcześniej przymiotników (miły, serdeczny, pomocny), a nie faktycznym opisaniem swojego zachowania. Świadomość własnych czynów, ich przyczyn, jak i konsekwencji może być również ważnym czynnikiem w tworzeniu swojej własnej tożsamości. Osoby badane są bardzo zaangażowane w swoje hobby - aktywnie w nich uczestniczą, co może wzmacniać poczucie własnej wartości. Mając świadomość tego, że w niektórych sferach życia potrzebują pomocy, badani próbowali ten fakt zataić, co w końcowym rozrachunku nie przynosiło zamierzonych efektów. Każda wypowiedź kończyła się wymienieniem choć jednej rzeczy, czynności, z którą wiążą się większe lub mniejsze problemy. Skutkiem takiego zachowania może być silna chęć samodzielności oraz samostanowienia.

\section{Jak osoba z niepełnosprawnością intelektualną w stopniu umiarkowanym myśli, że jest postrzegana?}

Obraz siebie bez wątpienia odgrywa dużą rolę w kształtowaniu się tożsamości. Wizerunek własnego „Ja” w oczach innych ludzi jest jednak równie ważny. Człowiek jest istotą społeczną, dlatego też warto dowiedzieć się, jak osoby z niepełnosprawnością odnajdują się w opinii społeczeństwa na ich temat. 
Na pytanie „Czy pamiętasz swoją szkołę?” większość badanych potrafiła dużo opowiedzieć o swojej dawnej szkole. $Z$ reguły były to miłe wspomnienia, opowiadanie o ocenach, przedmiotach i trudnościach.

Tak. Chodziłem do szkoły na ulicy [...]. Kolegów... trudno sobie przypomnieć. Tyle co Przemka. Rzadko kiedy mam z nim kontakt. (B.W.)

Pamiętam bardzo. Bo jestem $\mathrm{z}$ tej szkoły zadowolona. Byłam najlepsza w klasie. Byłam taka piątkowo-szóstkowa, bo z historii to szóstki same dostawałam. Z gazet przynosiłam takie większe i duże artykuły... i małe artykuły. I wszyscy byli ze mnie zadowoleni, że wszystko się udało w szkole. Ale mam i zdjęcia też czasami z przyjaciółmi i super mam takich przyjaciół... szkolnych można tak powiedzieć. (K.J.)

No to ja to bardzo dobrze pamiętam, bo się rozbeczałem na zakończenie roku. Poszedłem do szkoły w [...] roku do podstawówki. I raz nie zdałem pamiętam. Chodziłem do szkoły specjalnej połączonej z gimnazjum. Gimnazjum było w tym samym budynku. Yyy.... Na początku było łatwo, tak..., ale już potem pod górkę, już jak doszły inne przedmioty. Trzeba było się uczyć dzień i noc..., no. Ale no wytrwałem do tej trzeciej gimnazjum i ukończyłem tę szkołę. (M.G.)

Tak... Chodziłem do szkoły na [...]. Do szkoły zawodowej... skończyłem, zawód introligator... chodziłem... potem pracowałem jako introligator... W trzeciej klasie miałem zajęcia praktyczne i się kiedyś na nie spóźniłem. (M. I.)

Jedna wypowiedź była natomiast nacechowana negatywnymi emocjami. Badany bardzo źle wspominał czasy szkolne. Twierdził, że w wieku szkolnym był źle traktowany zarówno przez nauczycieli, jak i swoją matkę. Był siłą zmuszany do nauki.

Tak..., szkoła podstawowa z osobami takimi jak ja..., czyli z zespołem Downa. I tam chodziłem i miałem kolegów i koleżanki. Ale nie pamiętam już nikogo..., to było w tych... w latach 90 '..., a teraz to już współczesny wiek. Ale... oooohh! w szkole było strasznie! Nie lubię szkoły. Nigdy tam naprawdę nie chciałem chodzić. Była jedna dziewczyna... ode mnie chciała... dużo rzeczy trudnych. Taka szkoła to nie dla mnie, wolę już inną przyszłość. Ogólnie nauczycielki. Było tak, że mama mnie biła w domu! Mówiła „Ucz się pisać! Pisz, bo Ci zaraz dam... ten... no.... W szkole to źle miałem..., niedostateczny $\mathrm{z}$ historii. Nauczycielka była okropna $\mathrm{z}$ historii! Historia to tak, ale w szkole to..., a z gegry to już... Każdy mówi geografia, świetny byłem z tego..., a z historii najgorszy. Mama mówiła, że taki byłem dobry, wszystko umiem..., a nauczycielka mnie wyzywała..., dawała mi pały. Ale z gegry byłem najświetniejszy. Czy Europa tam... lodowce... to umiałem. Matmę miałem najgorszą. Nie umiałem nic z matmy! Kiedyś były liczydła..., o matko! Były najgorsze. Dodawać umiem..., wiem ile jest $8+8 \ldots$ to jest chyba 16 . (A.N.)

Wszyscy badani, przy pytaniu „Jak myślisz, co myślą o Tobie inni ludzie?” byli bardzo zmieszani. Każdy uczestnik badania po usłyszeniu pytania zamilkł na dłuższą chwilę i zawahał się co do odpowiedzi. Po chwili zastanowienia, każdy odpowiadał podobnie. Większość opisywała siebie jako miłych, pomocnych i sympatycznych. 
Niektórzy się ze mną po prostu witają, a to „dzień dobry”, a to „do widzenia”. Nieraz się śmiejemy, nieraz żartujemy. Jednym słowem..., że ze mnie taki żartowniś jest. Bo ja lubię żartować, powiem szczerze. (M.G.)

O mnie? The best! (P.G.)

Dwie osoby badane, zaczynając mówić o sobie, szybko zmieniały temat, unikając niejako odpowiedzi na zadane pytanie.

Że jestem dobrze wychowany..., że umiem... Czasem jak idę do ośrodka, to widuję tu... Pana Adama z ośrodka. (M.I.)

Jeden badany odpowiedział w sposób bardzo szeroki. Z tej wypowiedzi można wywnioskować, że badany ma świadomość konsekwencji swoich czynów. Wie, że ludzie mogą postrzegać go w różny sposób, zależny od tego, jak żyje.

Ehh... Albo dobrze myślą, albo źle. Zależy jakie świadectwo daję o sobie... dobry, uczynny i pomocny. (B.W.)

Podsumowując, osoby badane opisywały obraz własnego „Ja” stworzony przez siebie dużo łatwiej, niż ten stworzony przez innych ludzi. Badani, opisując swoją szkołę, w większości wypowiadali się o niej dobrze. Nie zapamiętali większych problemów związanych z okresem szkolnym. Instytucja szkoły mogła mieć wpływ na dalszą egzystencję oraz kształtowanie się swojego obrazu. Ciągłe chwalenie ucznia może wpłynąć na błędny obraz siebie. Większość osób uważa, że inni ludzie postrzegają ich tak, jak oni widzą siebie. Można zauważyć tu efekt egocentryzmu - skoro według mnie jestem fajny, to ty na pewno też tak uważasz. Dlatego też ważnym elementem w tworzeniu się tożsamości społecznej jest świadomość istnienia wielu punktów widzenia.

\section{Jaką rolę w procesie tworzenia się tożsamości osób z niepełnosprawnością intelektualną w stopniu umiarkowanym pełnią osoby najbliższe?}

Osoby, które mają trudności z ukształtowaniem swojej własnej tożsamości, bardzo często podatne są na przejęcie tożsamości osoby bliskiej, swojego autorytetu. Zadając pytania związane $\mathrm{z}$ tą tematyką, próbowałam znaleźć odpowiedź na ten problem badawczy.

Osoby badane w odpowiedzi na pytanie „Jaki jest Twój przyjaciel/przyjaciółka?” opisywały swoich przyjaciół jako osoby, które są dla nich wsparciem, na które zawsze można liczyć, które pomagają im w codziennych czynnościach. Zwracają też uwagę na to, że nie zawsze między nimi jest wesoło i przyjemnie.

Piotrek. Bartek czasami. U Piotrka cenię to, że jak coś mu tam odbije..., ale jak nie odbije, to kochamy się jak bracia, jak... ten... Syriusz Black i Harry Potter, jak bracia właśnie. Braterstwo, współpraca jednoczy nas właśnie. A Bartek, bo czasami ja mu pomagam przy 
dyżurze, to sobie pomagamy..., to on mi pomaga przy moim dyżurze..., tutaj się lubimy i... wzajemnie sobie pomagamy. To ważne, żeby wspierać, pomagać sobie nawzajem, czy w dyżurach, czy w zakupach właśnie. Znamy się z Piotrkiem od 2007. (A.N.)

Takiego mojego wiernego druha i kompana... Andrzeja. Ale ile się znam z nim? Ohoho!... około..., jak ja mam 40 to on ma $44 \ldots$, około... większość czasu się znamy z Andrzejem już. Kiedyś chodziłem do wspólnoty, teraz tutaj mieszkamy we dwójkę. Z nami jest jak z dobrym małżeństwem. Raz się kłócimy, raz się nie kłócimy. Wszystko jest najlepszej myśli. (B.W.)

Moim przyjacielem to jest Bartek i wierzę w niego..., zawsze będę w niego wierzył. Maryna też. Pomagam jej wsiąść... do autobusu..., pomagam jej zejść na piętro niżej. Robię jej miejsce, żeby usiadła i się przytrzymała. Bartek najlepszy, bo jest „taki gość”. To jeszcze moim przyjacielem jest Zbyszek. Zbyszek mój przyjaciel, dobry kolega. Pomaga wszystkim i mi też. (P.G.)

Tylko jedna osoba badana wypowiada się o swojej mamie jako najlepszej przyjaciółce. Świadczy to o bardzo silnym przywiązaniu do rodziny - w tym przypadku - matki.

Przyjaciela mam. Ale najbardziej mama! Mój przyjaciel..., co by się stało, to by w obronę wszedł i tą osobę... by coś zrobił. Inaczej. Mama najlepsza, bo mama pomaga. Ogolę się..., coś tam nie będę mógł, to poprawia. No..., mama najlepsza. (A.S.)

Na pytanie „Opowiedz mi o swojej rodzinie?” większość osób badanych wymienia swoją najbliższą rodzinę (ojciec, matka, bracia, siostry,) ale też babcię, kuzynów, wujków ciotki. Odpowiedzi badanych różniły się jedynie ilością dokładnych wiadomości na temat swojej rodziny. Niektórzy szczegółowo wymieniali, czym zajmują się członkowie ich rodziny.

Tatuś był rodowitym warszawiakiem. Od urodzenia mieszkał w Warszawie. Pracował w zakładach telekomunikacji. Wszystko tam robili..., a później pracę stracił..., potem... ileś czasu szukał pracy..., znalazł pracę prywatnie. Potem się mamusia zaczęła... chorować na raka. Z bratem mam bardzo dobry kontakt. Studiuje na Politechnice Warszawskiej..., elektrotechnik. Już ma magistra... będzie się bronił. Uczy się, pracuje. Co drugą niedzielę... umówiliśmy się... w zeszłym roku częściej, a teraz mówi, że co drugą niedzielę się będziemy spotykać. On może w pierwszą niedzielę sobie coś zaplanować... coś jechać, coś kupić, wymienić. $Z$ kolei..., wiesz jak człowiek pracuje od 7 do 16, to jak jedzie do domu, to jest już ciemno. Teraz też jak wyjdziesz do sklepu, to już wiesz... ciężko coś zaplanować. Z kolei po mamusi... Ciocię Danusię... też bardzo lubię do niej jeździć. (B.W.)

Tato jest tym... yyy..., pracował w zakładach mechanicznych jako dyrektor też jeszcze wcześniej bo jako menadżer i wszystko..., to mój tata tym wszystkim się zajmował i ten... i no... i jestem $z$ tego zadowolona, że mój tata jest taki przedsiębiorczy, lubi wyzwania i się zna na komputerze i czasami mnie uczy, jak się obsługiwać komputer czy coś tam. No i z wnuczki jest zadowolony, że ona wreszcie tą szkołę skończyła. No i studia..., a teraz pracuje i sprzedaje i kupuje i telefony i to i tamto i wszystko. Taki fajny biznes chcą z tatą zacząć, żeby umieć się czegoś nauczyć... i tata i ona. I zobaczymy, co z tego wyjdzie. (K. J.) 
Inni po prostu wymieniali, kto należy do ich rodziny, dodając krótkie informacje o poszczególnych osobach.

Tak, mam rodzinę w Poznaniu. Mama moja pochodzi..., poznanianka..., tam nad Notecią mieszkała. Moja mama miała mamę, ja babcię..., brata rodzonego..., swoją siostrę. Ojca to nie wiem..., bo ja ojca nie znałem. (A.N.)

Koniecznie...? Mam trzy siostry, jednego brata i jednego młodszego siostrzeńca... Znaczy... mam siostrzeńców. Mam takiego u macochy takiego... mój brat jeszcze u niej siedzi. (M.G.)

Mam rodzinę. Mamę swoją..., braci Krzyśka, Jarka, dziadka..., to też moja rodzina. I... jeszcze... a najbardziej to ja lubię całe mieszkanie wspomagane..., to też jak moja rodzina. (P.G.)

Podsumowując, zdecydowana większość osób badanych swoich przyjaciół określa względem korzyści, jakie ta przyjaźń przynosi. Badani przyjacielem nazywają te osoby, które pomagają im, oraz te, którym to oni mogą pomóc. Chęć odwdzięczenia się jest uczuciem empatii, które świadczy o rozwiniętej sferze emocjonalno-społecznej osoby badanej. Wśród opisu rodzin osób badanych rzuca się w oczy fakt, że wspominają one w swojej odpowiedzi tylko o jednym rodzicu. Przyczyną tego może być wychowywanie się w niepełnych rodzinach lub dominacja jednego rodzica w procesie wychowawczym. Wychowywanie się wśród tylko jednego wzorca zachowań, czy to męskiego, czy też żeńskiego, może zasadniczo wpłynąć na kształtowanie się tożsamości osób z niepełnosprawnością intelektualną.

\section{Jak plany i marzenia definiują tożsamość osoby z niepełnosprawnością intelektualną w stopniu umiarkowanym?}

W życiu człowieka planowanie przyszłości odgrywa dużą rolę. Aby planować, należy wiedzieć, czego oczekuje się od życia. Utworzenie zestawienia tego, co się ma, tego, co chce się osiągnąć oraz analiza możliwości osiągnięcia zamierzonych celów jest ważnym elementem w życiu każdego człowieka.

Na pytanie „Co chciałbyś zmienić w swoim życiu?” odpowiedzi można podzielić na trzy grupy. Osoba badana chciałaby radykalnych zmian w swoim życiu.

Wszystko. Mieszać sam bym chciał. Ogółem, no... znaleźć drugą połówkę. No i dogadywać się z innymi też. (M.G.)

Badany chce zmian jedynie niewielkich, ułatwiających mu funkcjonowanie w obecnej sytuacji lub zmiany pomagającej wyrwać się z rutyny, zmienić zajęcie.

Moje życie polega na tym, że czasem zmieniam się... Chciałbym zmienić otoczenie ludzi. Żebym był..., ja lubię zmienić takie otoczenie, żebym miał przyjaciół, kolegów... o tak bym to nazwał. (A.N.) 
Zachowanie... w zachowaniu nie chcę cały czas się kłócić..., nie chcę być czepialski. Staram się..., z trudnością przychodzi. (B.W.)

Chciałbym być aktorem. Iść w stronę... z kinem, jak Boguś Linda. Chciałbym być jak Boguś Linda. Takie buty ma ładne. Boguś Linda był teraz, widziałem jak był, z Sarą... tańczył. Albo karate po polsku. Zbysiu wziął do niej brzytwę. Dobrą akcję robią aktorzy. (A.S.)

Badany nie chciałby w swoim życiu żadnych zmian.

Nic bym nie chciała zmienić. Jaka jestem, taka jestem i nie chciałabym nic w swoim życiu zmienić... o! w taki sposób. (K.J.)

Chciałbym zmienić... nigdy bym nie zmienił. Nic nie chciałbym zmienić. (P.G.)

Przy pytaniu o plany na przyszłość „Jakie masz plany na przyszłość?” odpowiedzi były skrajne. Troje badanych w planach ma założenie rodziny, samodzielną egzystencję oraz prowadzenie własnego gospodarstwa domowego.

Plany na przyszłość? Gdybym nie był..., gdybym tutaj nie mieszkał, nie mieszkał u mamy to.. gdybym był pełnosprawny, to bym marzył o jednym..., tak jak ty... Masz chłopaka... narzeczonego i męża. Mam dziewczynę. Zakochałem się do... wiesz.... Dochodziło do konfliktów, ale nadal się kochamy i lubimy się. Ona ma rzut beretem. 520 można dojechać albo 35. I pojechałem $\mathrm{z}$ kwiatkiem na urodziny..., w listopadzie miała urodziny..., pojechałem z kwiatkiem, różą białą. Ja chciałbym, żebyśmy się kochali..., taka miłość na maxa. I mówię jej „Kochanie, życzę Ci dużo szczęścia radości... i żebyś mnie kochała... i dużo miłości w życiu”, a ona „Kocham Cię, dziękuję Ci za kwiatek”. (A.N.)

Takie jak i ty. Założyć rodzinę. Jak byłaby możliwość. Akurat w tym mieszkaniu wspomaganym..., i jak widzisz, każdy z każdym mieszka. Nie jest możliwością nawet seksu uprawianie tu. (B.W.)

Na przyszłość jakie plany? Żeby przyjść tutaj i jeszcze raz się podszkolić do domu treningowego. To jest raz, no i dwa, żeby... mieć własne dzieci i wychowywać. No i żeby założyć rodzinę. (M.G.)

Dwoje badanych skupiło się w swojej wypowiedzi na swoich planach zawodowych.

Na razie nie mam żadnych planów. Mam chłopaka..., na razie nie planujemy..., na razie ogólnie nic. Może przejmiemy kiedyś gospodarstwo po tacie moim, bo ten... tą działkę, którą mamy, to porozmawiamy i może uda się przejąć tę działeczkę, żebym miała także..., bo mamy i kwiaty, i trzeba porobić coś przy kwiatach... trochę doniczkowych, i takich..., i różnych. To takie przyjemności są właśnie... i przyjemne i sympatyczne robienie. Jest zadowolenie $\mathrm{z}$ tego, co się robi i zadowolona jestem z tego, co się robi na działce. No i teraz ekologiczne mamy warzywa i mój tata jest też zadowolony, że wszystko jest tak, jak powinno być i no... dobrze. (K.J.) 
Chciałbym być..., jakbym miał studio..., chciałbym być DJ-em. Dla mnie to jest za trudne wszystko... i za drogie. Trzeba mieć komputer..., wszystko trzeba mieć. (A.S.)

Dwoje badanych ma bardzo przyziemne plany na przyszłość. Brak w ich wypowiedziach długodystansowych planów działania.

Wyjście na spacer... Taki mam plan. (P.G.)

Jechać..., tak... ja jadę na wakacje do Zaździerza. (M.I.)

Po zadaniu pytania „Jakie masz marzenia?” tylko troje badanych potrafiło udzielić odpowiedzi. Reszta osób badanych nie odpowiedziała żadnymi słowami na postawione pytanie. Wśród uzyskanych odpowiedzi znaleźć można zarówno nietrudne do spełnienia, przyziemne marzenia, dalekosiężne plany zawodowe, jak i podniosłe idee, mające na celu poprawę funkcjonowania społecznego wszystkich osób z niepełnosprawnościami.

Marzenia mam... być historykiem jak mój kuzyn Jarosław! Uczy w szkole mój kuzyn. Najbardziej lubię historię. Najbardziej... od lat.. gdzieś tak... międzywojennych, o! i II Wojna Światowa... od rozpadu Austro-Węgier. Lata 90. też lubię... Okrągły Stół... Bierut, Gomułkę... o tak. (A.N.)

Żeby normalni ludzie traktowali osoby z niepełnosprawnością lepiej, inaczej, a nie po prostu... inni uważają, że inni... no żeby ludzie się zmienili. Ogółem, żeby nas akceptowali, bo niektórzy nie akceptują. Żeby się dogadywać z innymi normalnie..., a nie po prostu wysłuchiwać „ty upośledzony, ty taki i nie taki”. (M.G.)

Podsumowując, osoby badane mają różne podejście do swojej przyszłości, marzeń i planów. Niektórzy mają niezwykle trudne do osiągnięcia, ale jasno sprecyzowane cele (założenie rodziny, prowadzenie własnego domu), niektórzy myślą jedynie o kilku następnych dniach (wyjście na spacer, wyjazd na turnus rehabilitacyjny). Pytania o dalekosiężne plany i marzenia były jednymi z najtrudniejszych w tym badaniu, co potwierdza fakt, że nie wszystkim udało się na nie odpowiedzieć. Jasno sprecyzowane plany, marzenia, które są osiągalne, świadczą o dojrzałości oraz świadomości swoich praw, możliwości oraz posiadanych ograniczeń. Są to cechy, które opisują tożsamość osiągniętą.

\section{PODSUMOWANIE}

Przeprowadzone badania na celu miały uzyskać odpowiedzi, co wpływa na kształtowanie się tożsamości psychospołecznej osób z niepełnosprawnością intelektualną w stopniu umiarkowanym. By potwierdzić lub rozszerzyć spis czynników, należałoby poszerzyć grupę badawczą na większy zakres wieku, zwiększyć liczbę osób badanych czy też zróżnicować środowisko, z którego pochodzą. Warto zwrócić uwagę na przypadek badanego, który w okresie szkolnym nienawidził szkoły, nauki i był siłą zmuszany do uczenia 
się. Osoba ta teraz, kilkadziesiąt lat później, marzy o tym, by zostać historykiem, potrafi pisać, świetnie czyta (przeczytała kilkaset książek zarówno o tematyce historycznej, jak i powieści). Mimo trudności w okresie dziecięcym udało się tej osobie badanej wytworzyć swoją własną tożsamość.

Zrealizowane badania pozwoliły uzyskać odpowiedzi na postawione szczegółowe problemy badawcze. $Z$ analizy wyników przeprowadzonych badań można pokusić się o wysnucie kilku czynników, które wpływają na kształtowanie się tożsamości psychospołecznej osób z niepełnosprawnością intelektualną w stopniu umiarkowanym. Są to:

- Pełna świadomość posiadania niepełnosprawności, oraz znajomość jej charakterystyki.

- Akceptacja stanu, w jakim się aktualnie znajduje.

- Otwartość środowiska społecznego na jednakowe i sprawiedliwe traktowanie osób z niepełnosprawnością intelektualną na równi z osobami sprawnymi.

- Swoboda w kontaktach z innymi ludźmi.

- Wychowywanie się wśród różnych wzorców zachowań.

- Umożliwienie osobom z niepełnosprawnością intelektualną swobodnego wyboru drogi życiowej.

\section{BIBLIOGRAFIA}

Ambrozik, Wiesław, Kieszkowska, Anna (2012). Tożsamość grupowa dewiantów a ich reintegracja społeczna. Kraków: Oficyna Wydawnicza „Impuls”.

Bobińska, Kinga, Gałecki, Piotr (2012). Rys historyczny, terminologia, definicja, nozologia, kryteria rozpoznawania niepełnosprawności intelektualnej. W: Kinga Bobińska, Tadeusz Pietras, Piotr Gałecki (red.). Niepełnosprawność Intelektualna - epitopatogeneza, epidemiologia, diagnoza, terapia. Wrocław: Wydawnictwo Continuo, s. 21-40.

Brzezińska, Anna I. (2000). Społeczna psychologia rozwoju. Warszawa: Wydawnictwo Naukowe Scholar.

Brzezińska, Anna I., Piotrowski, Konrad (2010). Formowanie się tożsamości a poczucie dorosłości i gotowość do tworzenia bliskich zwiazków. „Czasopismo Psychologiczne”, 16(2), s. 265-274.

Giddens, Anthony (2008). Konsekwencje nowoczesności. Kraków: Wydawnictwo Uniwersytetu Jagiellońskiego.

Kowalik, Stanisław (1999). Psychospołeczne podstawy rehabilitacji osób niepetnosprawnych. Katowice: Wydawnictwo Śląsk.

Kowalik, Stanisław (2005). Psychologia niepetnosprawności umysłowej. W: Helena Sęk (red.). Psychologia kliniczna. Warszawa: Wydawnictwo Naukowe PWN, s. 135-155.

Łobocki, Mieczysław (1999). Metody i techniki badań pedagogicznych. Kraków: Oficyna Wydawnicza „Impuls”. 
Muszyński, Heliodor (1967). Metodologiczne problemy pedagogiki. Wrocław: Wydawnictwo PAN.

Obuchowska, Irena (1999). Dziecko niepetnosprawne w rodzinie. Warszawa: Wydawnictwa Szkolme i Pedagogiczne.

Pilch, Tadeusz (2001). Zasady badań pedagogicznych. Warszawa: Wydawnictwo Akademickie ŻAK.

Pilch, Tadeusz (1998). Zasady badań pedagogicznych. Warszawa: Wydawnictwo Akademickie ŻAK.

Piotrowski, Konrad (2013). Tożsamość osobista w okresie wkraczania $w$ dorosłość - Sytuacja młodych osób z ruchowym ograniczeniem sprawności i ich sprawnych rówieśników. Wielichowo: Wydawnictwo TIPI.

Schwartz, Seth (2005). A New Identity for Identity Research: Recommendations for Expanding and Refocusing the Identity Literature. "Journal of Adolescent Research", 20(3), s. 293-308.

Stelter, Żaneta (2007). Budowanie tożsamości przez osoby niepetnosprawne. W: Hanna Liberska, Barbara Harwas-Napierała, (red.). Tożsamość a wspótczesność. Nowe tendencje i zagrożenia. Poznań: Wydawnictwo Naukowe UAM, s. 181-205.

Wojciszke, Bogdan (2002). Człowiek wśród ludzi. Zarys psychologii społecznej. Warszawa: Wydawnictwo Naukowe Scholar. 